\title{
O FUTURO JÁ NÃO É O QUE ERA, MAS TERÁ DE SER MELHOR DO QUE PROMETE
}





\section{O futuro já não é o que era, mas terá de ser melhor do que promete}

Oração de Sapiência - 2019

Onésimo Teotónio Almeida

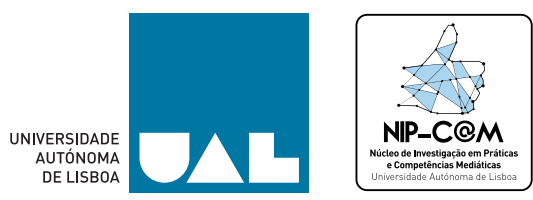




\section{Ficha Técnica}

\section{Título}

O futuro já não é o que era, mas terá de ser melhor do que promete

\section{Autor}

Onésimo Teotónio Almeida

\section{Organização}

Paula Lopes

\section{Edição}

(C) NIP-C@M - Núcleo de Investigação em Práticas \& Competências Mediáticas, Departamento de Ciências da Comunicação Universidade Autónoma de Lisboa

\section{Capa}

Bruno Filipe

Revisão

Madalena Romão Mira

Raquel Medina Cabeças

\section{Paginação}

Raquel Medina Cabeças

\section{Edição Digital}

Miguel Mendes Pereira

ISBN 978-989-9002-08-1

DOI http://doi.org/10.26619/978-989-9002-08-1

Handle http://hdl.handle.net/11144/4493

\section{Registo CIP}

Almeida, O. T. (2019). O futuro já não é o que era, mas terá de ser melhor do que promete. Lisboa: NIP-C@M. Disponível em http://hdl.handle.net/11144/4493. DOI http://doi.org/10.26619/978-989-9002-08-1

1. Filosofia; 2. Comunicação; 3. Futuro.

I. Almeida, O. T.

CDU 1 659.3 
Esta publicação obedece aos critérios de open access, estando cada capítulo assinalado com a licença Creative Communs, sem prejuízo do copyright pertencer aos autores e a publicação ao NIP-C@M da Universidade Autónoma de Lisboa.

A Cooperativa de Ensino Universitário, entidade instituidora da Universidade Autónoma de Lisboa, promove a produção científica em vários segmentos culturais, valorizando a relação entre a comunidade académica e a sociedade. Desta forma, apoia a edição desta publicação, contribuindo para a divulgação do conhecimento. 



\section{Índice}

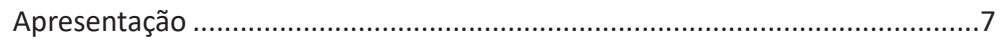

Reginaldo Rodrigues de Almeida

O futuro já não é o que era, mas terá de ser melhor do que promete ......................9

Onésimo Teotónio Almeida 


\section{Apresentação}

Reginaldo Rodrigues de Almeida Director do Departamento de Ciências da Comunicação

O modelo original de uma Oração de Sapiência ditava que fosse feita em latim mas, para nossa fortuna, o Professor Onésimo Teotónio Almeida usou a língua vulgar e todos, docentes e alunos, puderam usufruir de uma lição única e irrepetível. Apoiado na sua experiência de Diáspora, partilhou uma reflexão eminentemente prática, não obstante ser filosófica, O futuro já não é o que era, mas terá de ser melhor do que promete.

O sugestivo mas intrigante título foi, é, uma chamada de atenção sobre poderes, pluralidade, ética, responsabilidade e valores, escrito para o 350 aniversário da Universidade Autónoma de Lisboa, e lido para uma plateia entusiasmada, com um espírito que, infelizmente, não se trespassa para o papel.

Foi, pois, uma Oração de Sapiência, dita e sentida, cruzada com a boa disposição que o orador arrancava, com toda a facilidade, a uma assistência ávida pela leitura que nos ofereceu. Não sendo fácil fazê-lo, pareceu-nos natural vindo do Professor Onésimo Teotónio Almeida com uma Oração cujo fôlego vai dos gregos às redes sociais, numa sessão que ficará nos nossos anais.

Era impossível deixar este texto apenas na memória de cada um dos presentes, razão pela qual o Departamento de Ciências da Comunicação, com o aval do Autor, decidiu publicá-lo, com o privilégio de o partilhar em acesso aberto. 
A Universidade Autónoma de Lisboa agradece penhoradamente a este verdadeiro cidadão do mundo, cuja insularidade açoriana se esbate pelos continentes, um grande contador de histórias e de estórias, com a Vida como grande fascínio.

Fevereiro 2020 
Gostaria de começar por agradecer este verdadeiramente honroso convite que é, ao mesmo tempo uma enorme responsabilidade. Tendo aceitado vir de um outro universo falar a uma audiência naturalmente preocupada com os seus problemas específicos, sujeito-me a correr o grave risco de abordar questões inteiramente desfasadas da realidade da Universidade Autónoma de Lisboa.

Não é a primeira vez que aqui falo mas, quando o fiz, e por várias vezes na década de 90 , as responsabilidades eram bem menores.

Ao interrogar-me sobre que tema abordar propus o título divulgado no convite por se tratar de uma questão que emerge obsessivamente em conversas, como a que ainda recentemente tive com um brilhante aluno que se quis despedir de mim porque vai deixar a universidade e entrar no mercado de trabalho: Como vê o futuro? - Perguntou-me.

Evito o tema sempre que posso.

Cresci para o mundo na década de 1960, quando os jovens sonhavam um futuro com todas as marcas de uma utopia carregada de imensa ingenuidade. Todavia, era um imaginário ditado pelas linhas com que se cosia a nossa esperança, alimentada pelos autores que então líamos. Uns mais utópicos que outros, não os subcrevíamos por inteiro. Coabitavam em magote, como se num autêntico pot-pourri, de Karl Marx a Emanuel Mounier, o homem do personalismo. Se Camus também entrava, era porque, apesar das marcas deprimentes 
daquele Sísifo, ao menos nos apontava a liberdade, e a sua conduta humana era mais atraente do que a de Sartre. Na cesta, ou cabaz, cabiam Nietzsche e Neruda, Joan Baez e Bob Dylan, e até Freud e Marcuse, mas também Martin Luther King e João XXIII. Formámo-nos na crença no progresso ilimitado, apesar dos abusos dos que teimavam em pôr em prática os valores da modernidade, sem entenderem que ela tem de resultar forçosamente do equilíbrio entre esse mesmo punhado de valores, pois, nas suas versões absolutas eles são por natureza inconciliáveis.

Nós sabíamos como ia ser o futuro porque, se Hegel errara ao estancar a marcha da História fazendo-a atingir a perfeição na Prússia do seu tempo, nós acreditávamos na continuada reflexão das luzes, que projectavam sempre mais para diante e para o alto (se isto soar a Teilhard de Chardin, que hoje já ninguém sabe quem seja, pois que soe; não soará nada mal). Fui rousseauniano, como os meus companheiros de geração. $\mathrm{O}$ bom selvagem habitava por debaixo das superestruturas capitalistas que sabíamos de certeza iriam desabar um dia, com a ajuda do nosso empenhamento, e esse bom selvagem rejuvenesceria na sua candura inocente e total.

Mas o futuro já não é o que era. Não, não é esta a manhã que eu esperava e que a nossa geração se dispunha a produzir.

Recordo-me dos tempos em que me embrenhava em leituras sobre o futuro e hoje reconheço ter sido pura perda de tempo. Tenho vivamente na memória como se fosse ontem, o meu entusiasmo no início da década de 70 ao descobrir o bestseller 
de Alvin Tofler, Future Shock, que anunciava a throw away society. Seria consumir e jogar fora, pois, o que importava, era produzir para manter a máquina da economia em pleno funcionamento. Não demorou muito, porém, a surgir a consciência ecológica que gerou os movimentos a favor da reciclagem.

Não, não é pelo caminho das reflexões sobre ecologia que eu gostaria de ir.

Há quase quatro décadas que lecciono a alunos do 40 ano de licenciatura um curso interdisciplinar na Brown, cujo principal objectivo é levá-los a perceber que, apesar de estarem convencidos de que o paradigma dentro do qual o Ocidente hoje se move ser o da pós-modernidade, nós estamos ainda condenados ao projecto da modernidade - à falta de melhor. "Condenados" é um modo de dizer. Significa que não temos alternativa. Em ensaios e escritos diversos, tenho tentado explicar e justificar este meu ponto de vista, que não é algo em cuja defesa eu me sinta isolado. Por sinal, num livro que tenho entre mãos (quase a terminar a leitura) - Future Politics, de Jamie Susskind, editado no ano transacto pela Oxford University Press, com o subtítulo Living Together in a World Transformed by Tech ${ }^{1}-0$ autor, para quem a teoria política permite uma visão panorâmica da floresta que é a sociedade, abre a sua exposição declarando que irá tratar dos quatro conceitos mais básicos em política, a saber (Susskind, 2018: 10):

1 Susskind, J. (2018). Future Politics: living together in a world transformed by tech. Oxford: Oxford University Press. 
Poder: como os fortes dominam os fracos;

Liberdade: o que é que é permitido e o que é que é proibido;

Democracia: como podem as pessoas intervir na governação;

Justiça social: que deveres temos uns para com os outros.

Curiosamente, estes quatro conceitos básicos correspondem ao núcleo duro ou básico dos valores da modernidade.

Seria importante resumir aqui o que tenho escrito em lugares diversos, na tentativa de clarificar o conceito de modernidade enquanto visão do mundo que engloba um conjunto de crenças e valores, basicamente o que há décadas atrás era conhecido por lluminismo, filosofia das luzes (no mundo francófono), Enlightenment (no mundo anglo) e Aufklärung (em alemão). Com efeito, a partir de determinada altura, nos finais do século XVIII (tendo a surgir muito antes, está visto), a modernidade manifesta-se com facetas diversas (e sem sequer ser ainda reconhecida por esse nome), em múltiplas formas no Ocidente, sobretudo na França, Alemanha, Holanda e Inglaterra, mas não só. Inspirou a revolução francesa que, acima de tudo, foi uma epopeia contra a antiga mundividência herdada do universo medieval, mas ultrapassou as fronteiras europeias ao inspirar também a criação dos Estados Unidos. De resto, estes foram, no fundo, a primeira grande tentativa de materialização da utopia europeia da modernidade, chamemos-lhe assim. 
Postos estes prolegómenos, entremos nas definições de conceitos $^{2}$.

O melhor processo de uma aproximação do conteúdo implicado na ideia de modernidade será identificarmos as crenças dominantes associadas à visão que se sobrepôs à mundividência medieval. Elas são:

10 - O universo é conhecível e o ser humano é senhor do seu uso;

2ㅇ - Todos os seres humanos são livres e iguais';

3ㅇ - O ser humano é perfectível${ }^{4}$.

Subjacente a todos esses axiomas, e servindo-lhes de suporte, embora eles sejam aceites como inquestionáveis ${ }^{5}$, está a crença de que o mundo é bom. A razão passa a ser a linguagem-ponte que permitirá harmonizar aqueles axiomas entre si.

Não será necessário entrar aqui em localizações históricas do surgimento dessas crenças, mas presumo estar a pisar terreno seguro apontando para a institucionalização do protestantismo como a marca mais forte da viragem que constituíram.

2 Os próximos quatro parágrafos foram retirados quase verbatim de um texto meu anterior. Achei importante incluí-los aqui porque clarificam conceitos que usarei nas páginas subsequentes. "Modernidade, pós-modernidade e outras nublosidades", Cultura - História e Filosofia 22 (2006), pp. 49-69.

3 Este axioma tem sido objecto de grandes debates. Essa igualdade deve entender-se como igualdade de direitos, porque os seres humanos começam por não ser iguais logo ao nascer.

4 Devo a Cora du Bois o texto inspirador desta síntese, que tenho procurado desenvolver: "The Dominant Value Profile of American Culture", in Ronald Shinn, ed., Culture and School. Socio-Cultural Significances, San Francisco: Intext Educational Publishers, 1972, pp. 76-80.

5 Os autores da Constituição americana, um belo exemplo da tentativa de pôr em prática toda a mundividência da modernidade, chamaram-Ihes "self-evident truths". 
Do primeiro axioma resulta toda a legitimidade da ciência, da tecnologia e do capitalismo ${ }^{6}$. Na ciência, como em tudo mais, o critério fundamental de verdade vai fundamentar-se na experiência e na razão, já não na autoridade nem na revelação.

Do segundo axioma resulta a democracia, com os seus ideais de liberdade e igualdade, conflitivos e em busca de harmonização, mas nem por isso menos fundamentais ${ }^{7}$. Ao terceiro axioma está inerentemente associada a ideia de progresso e dela resultam todas as instituições destinadas a melhorar o ser humano e a torná-lo mais apto a usufruir dos bens viabilizados pelos axiomas anteriores. A educação, como meio de perfectibilidade, enquadra-se neste conjunto.

Atrás, referi subjazer a este tripé - ciência/tecnologia, liberdade/ igualdade e progresso - uma valoração ética fundamental: o mundo é bom. Não no sentido rousseaniano, mas em contraposição às crenças da teologia cristã medieval que considerava o mundo um lugar de passagem, e inimigo dos seres humanos por ser capaz de pôr em perigo o Outro Mundo, o verdadeiramente Bom. É sabido quanta influência a teologia protestante (a teologia das realidades terrestres) exerceu sobre a teologia católica, que precedeu a criação de um documento como a Gaudium et Spes no Vaticano II. Quanto à origem protestante de uma atitude positiva em relação ao mundo

6 Ver Weber, M. (2005). A Ética Protestante e o Espírito do Capitalismo. Lisboa: Presença; e Merton, R. (2002). Science and Technology in Seventeenth Century England. Howard Fertig Pub.

7 A teoria da justiça proposta por John Rawls é a mais eloquente demonstração de que as grandes questões da ética contemporânea se resumem a uma harmonizacão dos princípios da liberdade e da justiça. Ver Rawls, R. (1971). A Theory of Justice. Cambridge, MA: Harvard University Press. 
material, basta recordarmos aqui a tese de Max Weber sobre a ética protestante e o espírito do capitalismo, nomeadamente os capítulos relativos ao surgimento do "ascetismo terreno", por oposição ao ascetismo voltado para o "Outro Mundo".

Não será difícil entrarmos em acordo quanto a estes valores. A pergunta que neste momento estará nas mentes de muitos dos presentes calculo ser esta: e que futuro têm esses valores no Ocidente?

A pergunta é mais do que válida. Confesso que há muito poucos anos eu teria uma resposta clara: temos de nos agarrar aos valores da modernidade, compreender que nenhum deles é absoluto e procurar harmonizá-los da melhor maneira possível, utilizando os meios legais e institucionais ao nosso alcance para garantir que os estados de direito desenvolvam e solidifiquem estruturas legais e políticas, que garantam aos processos democráticos assegurar a salvaguarda desses mesmos valores, de modo a eles ficarem acessíveis ao maior número de cidadãos e nas proporções mais equitativas.

Todavia, algo mudou entretanto.

Há muito, pensadores modernos mais atentos deixaram de acreditar na inevitabilidade do progresso (não na importância ou conveniência dele), mas vale a pena destacar também a sua contingência porque a evolução significa necessariamente progresso. Estava enraizada no imaginário ocidental a conviç̧ão de que a racionalidade conseguira já um tal elevado grau de institucionalização que o progresso se tornara uma direcção normal e indiscutível. 
Antes de prosseguir, gostaria de esclarecer o que significa para mim racionalidade.

Permitam-me alguns preâmbulos a assentar conceitos para tornar mais facilmente entendível a minha linguagem.

Primeiro - quando falo em racionalidade refiro-me àquela actividade mental que vê, organiza, interrelaciona e pesa as realidades consignadas em palavras, seguindo regras de coerência e lógica. Digamos que é o nosso olhar do mundo do ponto de vista lógico. Trata-se apenas de uma dimensão da vida humana, e ela está envolta num universo difuso de emoções e crenças que the escapam.

Segundo - as emoções, por pertencerem a uma outra dimensão do real, são impulsos que nos permitem olhar para as coisas do ponto de vista da sua bondade ou maldade e da sua beleza ou fealdade. Esta perspectiva constitui, portanto, a esfera dos valores (ou da axiologia), que se dividem entre os da ética e os da estética.

Foi a racionalidade assim considerada que Max Weber apontou como sendo a novidade introduzida pelo protestantismo na esfera da actividade económica. Já não era apenas o impulso aquisitivo a incitar uma actividade cega; a racionalidade alargara significativamente a sua intervenção a ponto de calcular analítica e friamente todo um sector da actividade humana - o económico. A razão procura articular coerente e logicamente os nossos valores que, por sua vez, se movimentam numa esfera não-racional. Não quero dizer "irracional", pois não é o caso. 
É mesmo "não-racional", por os valores serem de natureza diferente da razão.

Esta distinção tem servido de pano de fundo à institucionalização do Estado de direito e das instituições que o asseguram. Estávamos convencidos de que, muito embora a perfeição fosse impossível, aos poucos, as instituições fundamentais do Estado de direito ir-se-iam autocorrigindo e, com a ajuda da moderna tecnologia, simultaneamente aperfeiçoando.

Havia a ideia de ordem e progresso, entranhada na nossa visão herdada do iluminismo, reforçada pelo positivismo de Augusto Comte, a mesma que os líderes da independência do Brasil interiorizaram consignando-a na sua bandeira, uma das que usa palavras no estandarte nacional - Ordem e Progresso. Depois, sobretudo a partir da década de 60 , com o marxismo a alumiar um futuro de amanhãs que cantavam, e após a queda do muro de Berlim, enraizou-se firmemente a ideia de que caminhávamos para uma sociedade civil civilizada, cada vez mais ordeira, porque cerebralmente articulada dentro dos parâmetros da democracia liberal. Nos EUA, por exemplo, ela conduziu à eleição de Obama. Um negro na Casa Branca era a prova provada de que o rumo do futuro estava decididamente entranhado no subconsciente colectivo do Ocidente. Os EUA lideravam porque, embora tivessem bebido os ideais da modernidade na Inglaterra e particularmente em França (neste último caso em especial por intermédio de Thomas Jefferson e seus correligionários), tinham uma sociedade toda construída a partir do zero, flexível portanto. $\mathrm{O}$ facto de ali se ter fixado 
uma população advinda de todos os cantos da terra permitia ao país funcionar como um cadinho onde se ensaiava o futuro para onde o mundo todo - ou, pelo menos, o ocidental - caminharia seguindo a sua pegada. As outras nações viriam atrás, cada uma ao seu ritmo; o rumo à vitória estava inscrito nos ventos da história, e esta não seria marxista, mas a da democracia liberal. John Rawls, no seu já clássico Uma Teoria da Justiça, oferecera o travejamento final de que o pensamento ocidental necessitava. $O$ resto seria, não propriamente o fim-da-história preconizado por Fukuyama, mas um caminhar constante e seguro, na certeza de que o amanhã seria melhor do que hoje.

$\mathrm{E}$, de repente, parece que tudo se desmoronou. Foi como se finalmente estivéssemos a ver uma luz no fundo do túnel, mas era... o comboio. Aqui começa, pois, a mais recente viragem no percurso dos valores da modernidade no Ocidente. $\mathrm{O}$ aviso viera, aliás, muito antes da eleição de Obama, com o 11 de Setembro de 2001. Às portas da democracia havia afinal insuspeitadas forças, capazes de abalar fisicamente os mais imponentes arranha-céus como as Torres Gémeas, vigoroso símbolo poderoso do poder ocidental. Mas, na verdade, só mais tarde nos apercebemos de um outro abalo profundo a agitar as instituições e a provocar mudanças, de que a eleição de Trump foi apenas outro sintoma.

E quais terão sido essas alterações profundas?

Do meu ponto de vista, a mais colossal foi a revolução nas comunicações trazida pela informática - pelo mero facto de ter provocado precisamente aquilo que os seus criadores 
anunciaram como um grande passo rumo ao progresso. Qualquer pessoa passaria a ter voz, teria acesso imediato a um microfone e a um público. Ser-lhe-ia possível, em instantes apenas, divulgar as suas ideias num blogue ou nas redes do Facebook, do Instagram ou do Twitter. E mais, poderia simplesmente intervir e comentar qualquer notícia ou artigo de opinião publicado num jornal online, algo que anteriormente só uma reduzidíssima minoria conseguia fazer através de uma carta ao director.

Essa revolução democrática iria transformar implacavelmente o mundo e a política. E fê-lo, sem dúvida, se bem que não necessariamente na direcção sugerida e/ou esperada.

Aviso que o que direi a seguir parecerá eventualmente reaccionário ou antidemocrático. Feito o aviso, prossigo sem remorsos.

Racionalistas, marxistas, teóricos da democracia, todos de uma maneira ou de outra, ignorámos o lado animal da natureza humana. Tal como Marx - que foi um ingénuo discípulo de Rousseau, ao acreditar piamente que o bom selvagem tinha sido destruído pelo capitalismo mas, irradicado este, voltaria à sua bondade natural - acreditámos também na intrínseca bondade do ser humano. Os teóricos da democracia foram inconscientemente alimentados por uma versão angloamericana do hegelianismo: acreditaram que a razão triunfaria sobre todas as outras forças, porque estavam já criadas e alicerçadas as instituições democráticas capazes de assegurar o domínio dela. O sistema americano era o supra-sumo desse 
triunfo com o seu perfeito equilíbrio entre os três poderes o legislativo, o judicial e o executivo. Todos os casos estavam previstos e, na eventualidade de surgirem novidades sócioculturais inesperadas, as emendas à Constituição resolveriam potenciais problemas, simplesmente adaptando aos tempos modernos os princípios estabelecidos pelos Founding Fathers.

Entretanto, há mais de um século e meio, Nietzsche, no extremo oposto ao marxismo, libertara a mente ocidental, apontandoIhe o caminho da liberdade total, que incluia a libertação de todos os impulsos naturais de animalidade, latentes nos seres humanos.

Se isso permitiu aos pensadores democratas o corte de amarras de todas as imposições da moral tradicional, permitiu também aos conservadores o soltar de todos os instintos, incluindo aqueles para que Thomas Hobbes havia chamado a atenção e por causa dos quais ele advogava a intervenção do Estado forte - o Leviatã. Porque para Hobbes o homem era um animal, uma besta, um lobo e um lobo do outro homem, o Estado tinha de ser forte e duro para admoestá-lo ou, pelo menos, refreá-lo vigorosamente.

A Internet veio permitir que toda esta animalidade, accionada por crenças metafísicas e respectivos valores de fundo, se aproveite das redes sociais para expressar os seus pontos de vista. Até aqui, não adviria ainda grande mal, se não acontecesse 
a possibilidade de se ir mais longe intervindo anonimamente e falsificando factos e realidades ${ }^{8}$. Ao contrário de antigamente, quando os meios de comunicação social tinham as suas equipas especializadas de fact-checkers e só arriscavam publicar informações e emitir opiniões devidamente fundamentadas, porque os tribunais poderiam sobrevir-lhes com processos por difamação, actualmente nas redes sociais tudo pode circular livremente e sem controlo.

Grupos tecnicamente evoluídos podem criar contas anónimas, adquirir listas fabulosas de endereços, e divulgar informações falsas que influenciam os leitores que, ou não têm capacidade crítica para avaliar o material recebido, ou não possuem meios nem tempo para apurar a verdade do que lêem, ouvem ou vêem em imagens. Quando grupos especializados vêm a público desmascarar as falsidades espalhadas, é em regra demasiado tarde porque os leitores, ouvintes ou espectadores de notícias, já estão entregues ao consumo de novas falsidades.

O anonimato em que grande parte de toda esta informação é veiculada constitui a grande novidade dos tempos de hoje. $\mathrm{Na}$ comunicação pré internet uma fonte poderia ser anónima, mas

\footnotetext{
8 Poderia aqui citar uma longa lista de dados, mas limito-me a um pequeno exemplo muito recente retirado de The Washinton Post de ontem (e poderia ser de The New York Times ou de The Boston Globe). No artigo de opinião "Dishonesty and dirty tactics define British election" Rick Noack escreve: "There was a time, not long ago, when Britain's election broadcasting rules largely ensured that candidates got fair access to the limited number of true mass media outlets that shape public opinion. Britain's approach has evolved over time. But as the campaign for Thursday's general election has shown, the media landscape has changed such that mere tweaks may no longer be sufficient. Throughout this campaign, dishonest claims and dirty tactics - spread predominantly online - have rendered the frameworks that once ensured at least a certain degree of fairness during political campaigns largely useless. (The Washington Post, 12 de Dezembro de 2019). O sublinhado a negro é da minha responsabilidade.
} 
teria de estar identificada na redacção, pois esta era responsável perante os tribunais. Hoje isso desapareceu.

Platão contou na sua República a fábula de Giges, o pastor Glaucon, o qual encontrou um anel cuja pérola, quando voltada para a palma da mão, tornava invisível o seu dono. Esse dono poderia pois como entendesse, sem ninguém o ver ou suspeitar da sua existência e actividades. A consciência de que alguém nos está vendo praticamente se desvaneceu do nosso universo, pois hoje, na Internet, é como se todos pudéssemos actuar como o pastor da história de Platão, agindo anonimamente sem receio de sermos responsabilizados (não recordo quem, talvez influenciado por esta ideia platónica, afirmou que a consciência é o sentimento de que alguém está a ver-nos). Deste modo, as forças do super-ego, que tradicionalmente nos impediam de agir egoistamente e de modo descontrolado, sentem-se libertas para intervir na defesa e propagação dos mais animais sentimentos imagináveis.

Nietzsche, o grande contemporâneo da velha luta contra Marx (na sua visão marxista do mundo, Foucault integrou uma dimensão totalmente nietzschiana: a ideia de que o que conta é o poder e cada qual age para estabelecer o seu) - Nietzsche, dizia eu, libertou, legitimando-a, toda essa vertente animal da natureza humana (não é aqui o momento de explicar em pormenor esta afirmação; fi-lo noutro lado, no meu livro De Marx a Darwin - a desconfiança das ideologias ${ }^{9}$ - todavia espero futuramente desenvolver um pouco mais essa ideia).

9 Lisboa: Gradiva, 2009; 2o edição, 2017. 
O lado biológico, genético, se quisermos, da natureza humana foi sistematicamente ignorado pelos teóricos e cientistas sociais até surgir o movimento da sociobiologia, influenciado pelo trabalho de biólogos e zoólogos que nos anos 60 e 70 se dedicaram ao estudo das sociedades animais e daí, por analogia, extrapolaram conclusões para a sociedade humana. Hoje a designação "sociobiologia" desapareceu e foi substituída por "psicologia evolutiva". Independentemente do nome que the quisermos dar, parece mais do que claro que as forças animais são poderosas em nós, e preferem manifestar-se no escuro, às escondidas, se possível à margem da lei e dos olhares da comunicação social.

Foi assim que chegámos às fake news, ao desinteresse pela questão da verdade, e à vulgarização da ideia nietzschiana de que não há factos, apenas interpretações; de que a opinião de cada um é tão válida como a de qualquer outro e que, em democracia, ganha o mais forte, isto é, o que consegue mais votos, porque a verdade é democrática.

O problema, porém, está em que os valores são democráticos, todavia a verdade não é. Reconhecendo embora que não existe a Verdade com maiúscula (pelo menos não é acessível por meios humanos ao comum dos mortais, pois ninguém tem acesso a ela), temos obrigação de procurar a verdade do que é conhecível, e há regras solidamente estabelecidas ao longo de milénios para lá se chegar. Os silogismos de Aristóteles ainda mantêm a sua validade e a ciência moderna tem mais de 300 anos de resultados palpáveis. A ciência não o é, nem se pretende, democrática 
porque não depende dos votos da maioria. Há maiorias sim, mas maiorias inter pares. Em determinados tempos o consenso da maioria dos pares é que constitui a verdade operacional (já o nosso Francisco Sanches tinha, em parte, aí chegado, e Karl Popper redigiu preto no branco o que hoje é consensual).

O receio de figurar negativamente na primeira página de um jornal já não é um freio. Há quem não se importe, quem pense que afinal não há má publicidade. Toda a publicidade é boa, pois contribui para o reconhecimento do nome e um nome reconhecido é fonte de poder. Falem de mim, mal ou bem, desde que falem - é a palavra de ordem desse modo de pensar. De tanto ter aprendido sobre as podridões que se escondem por detrás de tantas instituições antigamente tidas por veneráveis desde as religiosas às universitárias, e à família - a consciência público tornou-se insensível ao escândalo. Somos todos iguais e, no fundo, todos somos animais, já não com pecados porque o conceito desapareceu, mas com peccadillos próprios do ser humano. Quer dizer: hoje, já nem vale mais aquela versão moderna da "regra de ouro" (Não faças aos outros o que não queres que te façam a ti) que remonta a Confúcio e aparece no Antigo Testamento, Tudo o que fizeres, fá-lo de tal modo que não te envergonhes se um dia isso aparecer na primeira página de um jornal.

A comunicação social, no seu afã de desvendar a verdade, destruiu os ídolos do presente e os académicos encarregaramse de destruir os do passado, que também hoje já não é mais o que era. Se todos os seres humanos são sujos e têm esqueletos 
no armário, nem os pilares da Igreja ao mais alto nível escapam. Então eu, que sou um simples humano, também não posso escapar. Que ganhe o mais forte! - tornou-se pensar corrente.

Trump, por exemplo, é apenas um expoente máximo desse modo de pensar, para cúmulo com imensa mais visibilidade. Seguem-se-lhe os Bolsonaros e tantos outros por aí.

Leio Nietzsche há quase meio-século (releio-o todos os anos porque faz parte da bibliografia do tal curso que referi no início), e nunca imaginei que um dia havia de ver em carne e osso a caricatura do super-homem. Aposto que, sem ele nunca ter lido o filósofo de Assim Falava Zaratustra, intuitivamente a figura em causa terá cheirado no ar o espírito do tempo e... incarnou-o. Na moral de Nietzsche, o espírito nobre é o que declara boas as coisas que lhe convêm. Porque, como atrás referi, não há factos, apenas interpretações. A citação de Píndaro - Torna-te no que és! - funciona para Nietzsche como apelo à animalidade natural ao tornar-nos inocentes sem controlo de quem-querque-seja porque, como seres livres, somos deuses. Ou pelo menos semideuses. $\mathrm{O}$ cordeiro pode protestar ao ser assaltado pela águia, contudo a reacção dela é simples: Não tenho nada, nadinha, contra ti. Só que a tua carne é muito gostosa. Daí vai um nada até chegar-se à descarada afirmação: "I could stand in the middle of 5th Avenue and shoot somebody and I wouldn't lose voters" 10 .

Não invento. $O$ modelo é Nietzsche sem tirar nem por, e vem no seu A Genealogia da Moral. Nunca imaginei, porém, ver

10 Afirmação de Donald Trump durante a campanha eleitoral em 2016. 
esse livro feito Bíblia do líder número um do planeta e, pior ainda, alguém que apregoa essa doutrina como cristã, sendo fortemente aplaudido pela falange evangélica, quando toda a vida intelectual de Nietzsche se concentrou na destruição do cristianismo. Como se sabe, Nietzsche via-se mesmo como o Anticristo.

Quem havia de dizer que um dia nos havíamos de deparar com semelhante doutrina feita Evangelho? Até Walt Whitman, o mais nietzschiano dos poetas norte-americanos, deve estar a dar voltas no túmulo.

Os EUA foram, até há pouco, um farol do futuro. O próprio Reino Unido, um dos berços e pilares da modernidade, está entregue às mesmas forças não-racionais, tal como a China e a Rússia se entregam às suas.

O mundo de hoje é uma luta de super-potências e a ideia clássica da democracia, de nos sentarmos à mesa a discutir calma e friamente os problemas, parece não conseguir mais vingar. Nem sequer a ciência, que até aqui vinha a ganhar terreno e a imporse com uma autoridade baseada em resultados palpáveis, tendo manifestado na viagem à Lua de 1969 a mais espectacular prova susceptível de impôr respeito.

Qualquer avanço da ciência é hoje posto em causa por inconfessados e escondidos interesses de multinacionais, mas também por vozes anónimas movidas por obscuras razões, que se arrogam o direito de reclamar pé de igualdade no conhecimento, e se expressam nas redes sociais pura e simplesmente tentando 
desacreditar o trabalho sério de milhares de cientistas que passam a vida a estudar a fundo problemas que nos afectam a todos.

Os Trumps e Bolsonaros de hoje desdenham da ciência e dos cientistas, por mais laureados que sejam, e denunciam-nos publicamente quando as suas posições entram em conflito com as do poder. Recomendar-Ihes que leiam o precioso livro Why Trust Science? de Naomi Oreskes ${ }^{11}$, recentemente publicado e que ainda tenho entre mãos, seria absolutamente inútil. Todavia , posso fazê-lo àqueles que estão dispostos a continuar a batalha, ainda que sabendo que a guerra está longe de ser ganha.

Não sou ingénuo. Não partilho da visão exagerada de alguns cientistas e há um português que a tem afirmado, como fez não há muito numa entrevista à Folha de S. Paulo, no Brasil:

[...] filosofia não é ciência, porque nunca progride. Eu tenho o maior respeito pelos filósofos porque o objetivo da filosofia é o mesmo que o da ciência: explicar o mundo e a nós próprios. Agora, nós temos um bom processo e eles não têm, portanto estão fadados a desaparecer. O que é o objetivo da filosofia vai ser resolvido pela ciência, e a filosofia vai passar a história ${ }^{12}$.

É deveras um caso de déjà vu all over again, como o outro dizia. Lembram-se de Daniel Bell e do seu famigerado The End

11 Princeton, New Jersey: Princeton University Press, 2019.

12 Alberto Nóbrega, entrevistado por Cristina Caldas para a Folha de São Paulo (02.06.2018). Entrevista disponível em: https://www1.folha.uol.com.br/ilustrissima/2018/06/filosofianao-e-ciencia-e-esta-fadada-a-desaparecer-afirma-pesquisador.shtml. 
of Ideology, de 1960? A ciência e a tecnologia iam resolver os problemas todos do mundo, mas de repente sobreveio a ideologia marxista a imperar durante décadas. Agora é a ideologia nietzschiana (sem lhe citarem o nome) e alguns cientistas achando que podem superá-la rejeitando a existência de valores que subsistem, apesar de não pertencerem ao domínio da ciência. A axiologia é um universo totalmente diferente da epistemologia. Por outras palavras, os pontos de vista da ciência e da ética não são antagónicos. Entrecruzamse inevitavelmente. A ciência não elimina a ética. Seria preciso voltarmos à dilucidação de conceitos com que abri esta minha charla. Face às aberrações dos relativistas em epistemologia, e apesar das afirmações exageradas do referido cientista, há que defender a ciência. E aqui as universidades têm um papel fundamental. No entanto, já Max Weber estabelecera a diferença entre o cientista enquanto (qua) cientista e (qua) cidadão. $\mathrm{O}$ cientista busca a verdade dos factos para entender $\mathrm{O}$ real; o cidadão lida com os valores e procura defender aqueles que mais estima. Nenhum dos lados pode ignorar o outro.

O futuro não poderá impedir a ciência de continuar a avançar na exploração do conhecimento e os valores da modernidade - de que a ciência faz parte integrante - não poderão ser abolidos. Terão de continuar a ser prosseguidos veementemente, através dos meios disponibilizados pelas instituições laboriosamente estabelecidas ao longo de séculos.

Não podemos abdicar dos valores da modernidade. Há que defender convictamente a ciência, a liberdade, a justiça e 
o progresso, conscientes de que nenhum desses valores é absoluto e que eles todos se imbricam uns nos outros. A prática da democracia é a única maneira que temos de lidar com todas essas realidades e há que seguir-lhe as regras. A alternativa é o might is right - o mais forte é que tem razão (o reino absoluto da visão com que Spencer resumiu o darwinismo) - causando em última instância a anarquia e a guerra civil.

Gosto da metáfora do velho sistema de transportes no rio Tamisa, no Reino Unido. Um barco era amarrado por duas cordas a dois cavalos, cada um na sua margem do rio. Os cavalos avançavam pelo rio acima puxando o barco, cada um do seu lado. Daí resultava que o barco singrasse direito pelo meio do rio.

Hoje, como que se atingiu um nível de paralização total: os cavalos, em vez de caminharem para diante fazendo avançar o barco, puxam cada qual para seu lado a ponto de o barco permanecer imóvel. Pior, chega quase a despedaçar-se. Olhe-se para os EUA e o Reino Unido de hoje.

Há que voltar à conversação democrática, à tolerância, ao reconhecimento de que é preciso manter o coração quente na luta, mas a cabeça fria na análise, e só isso permitirá atingirse o compromise (o termo ainda não é corrente em português neste sentido anglo-americano de cedências mútuas na luta pelos interesses individuais e de grupo), o acordo de cavalheiros que decorre de cedências, de trocas, de consiliências, para usar a expressão do grande pensador da modernidade, o zoólogo Edward O. Wilson ${ }^{13}$.

13 Wilson, E. O. (1998). Consilience. The Unity of Knowledge. New York: Vintage Books. 
Tanto são legítimos os valores da esquerda como os da direita, porque os valores não têm base científica e as suas escolhas não dependem da ciência ou da verdade, visto entroncarem em visões do mundo com raízes por vezes metafísicas, inteiramente fora do âmbito da ciência. Tanto um lado como o outro, em regra, apenas estabelece diferentes prioridades ou hierarquias na sua ordem de valores. Mas ambos os flancos do espectro político estão sujeitos à busca da verdade porque, para raciocinarmos sobre os grandes problemas da vida, temos de ter bases empíricas sólidas naquilo que aos factos diz respeito. Todos nós sabemos da dificuldade de, na política, haver uma prática absoluta da verdade; todavia, é inadmissível que o líder de uma democracia ocidental habitue os seus eleitores a uma média de vinte mentiras por dia (e isto é um facto; não uma opinião politizada ${ }^{14}$ ).

Com a esfera dos factos hoje tão à mercê de interesses obscuros de grandes forças económicas e políticas, há que agarrar-nos à comunicação social que permita ser, como a melhor dela vinha sendo até há pouco - o quarto poder, aquele que garante ao público uma informação resultante de aturada investigação, de modo a esse público poder tomar decisões devidamente educadas.

Tudo isto é cada vez mais difícil, num mundo em que países como a China e a Rússia controlam as suas verdades. Mas a isso

14 A contagem pode variar, mas as estatísticas são altíssimas. Veja-se esta reportagem da CNN: "From an imaginary restraining order to a phantom drop in NATO spending: Trump makes 99 false claims in two weeks", por Daniel Dale and Tara Subramaniam, disponível em: https://www.cnn.com/2019/12/21/politics/fact-check-trump-twoweeks-december/index.html. 
estávamos há muito habituados. O que é novo é o potencial incomensurável de que dispõem para intervir no nosso universo, sobretudo via Internet. Também é novo o facto de até os EUA se terem abrasileirado, como Richard Rorty apontou há algumas décadas no seu Philosophy and Social Hope ao referir o fenómeno do incremento do desnível económico na pirâmide social americana ${ }^{15}$, a ponto de forças económicas monumentais poderem interferir no controlo da informação, operando modificações indetectáveis e alterando factos, manipulando-os em prol dos seus interesses e usando a Internet para disseminar outros "factos" recriados em benefício próprio.

É, por isso, imperativo apoiar o quarto poder da comunicação social, ainda relativamente livre, de modo a que possamos manter o necessário espaço de respiração ${ }^{16}$.

Iniciei esta texto referindo o recente livro de Jamie Susskind, Future Politics, que advoga a luta pela coexistência de potentados, numa espécie de Confederalismo Digital porque os monopólios estrangularão a liberdade. Por isso, há que lutar contra esses potentados assegurando a co-existência de poderios económicos. Mesmo que os meios de comunicação possam estar ao serviço de interesses, a sua existência plural

15 Quatro dias depois da leitura do presente texto na UAL, deparei com uma reportagem publicada pelo New York Times (17 de Dezembro de 2019) sob o título "Among the world's most dire places: this California homeless camp", da autoria de Thomas Fuller and Joseph Haner, comparando um campo de sem-abrigo em Oakland às favelas brasileiras: https://www.nytimes.com/interactive/2019/12/17/us/oakland-californiahomeless-camp.html.

16 Rorty, R. (1999). Philosophy and Social Hope. London: Penguin. Ainda há dias recebi do The Washington Post um email com um relatório exclusivo intitulado "The Afghanistan Papers: a secret history of the war". O "Subject" do email anunciava: "Your subscription enabled this exclusive three-year investigation". 
assegurará um espaço de liberdade a fim de que a verdade, tanto quanto possível não deformada por interesses privados, possa sempre encontrar um microfone, uma câmara de TV, um blogue ou uma página de jornal.

Não parece bonito o futuro... (não resisto a lembrar aquele diálogo entre um pessimista e um optimista. O pessimista declarou desiludido: Isto está tão mau, tão mau que não pode ficar pior! O optimista reagiu: Ai, pode, pode!)... mas será mais feio se abdicarmos da luta pelos valores da modernidade. Se nas universidades não conseguirmos incutir nos nossos alunos o sentido da responsabilidade ética, da importância do estudo, do trabalho afincado, porque cada vez menos as coisas cairão do céu e não triunfará nunca quem cruzar os braços (a não ser pela lotaria, ou por ter nascido em berço de oiro) falharemos na nossa missão. E se esses valores podem e devem ser transmitidos por todos os professores, cabe sobretudo às Humanidades e às Ciências Sociais um papel especial nesse domínio. Aliás, não só de intervenção nas aulas, mas também no próprio espaço público. Se foram ilusão pura os amanhãs que hoje supostamente cantariam, ainda não estamos de modo algum condenados a amanhãs de lágrimas. Assim, tenhamos a sabedoria de tomar consciência e agir oportuna e firmemente. 




\section{O FUTURO JÁ NÃO É O QUE ERA, MAS TERÁ DE SER MELHOR DO QUE PROMETE}

Onésimo Teotónio Almeida

ORAÇÃO DE SAPIÊNCIA 2019

Universidade Autónoma de Lisboa

O núcleo de investigação NIP-CRM, unidade do Departamento de Ciências da Comunicação da Universidade Autónoma de Lisboa, tem por objetivo potenciar sinergias entre docentes e discentes para a conceção e desenvolvimento de projetos de investigação no âmbito das práticas e competências mediáticas digitais. Este espaço de investigação constitui-se como um campo aberto de discussão e reflexão, podendo ser integrado por todos aqueles que manifestem vontade em contribuir para a concretização de atividades coerentes com o espírito do núcleo.

\section{NIP-CRM}

